\title{
Harga-diri (Self-esteem) Terancam dan Perilaku Menghindar
}

\author{
Wilis Srisayekti', David A. Setiady ${ }^{2}$ \\ Universitas Padjadjaran, Bandung, Indonesia \\ Rasyid Bo Sanitioso ${ }^{3}$ \\ Université René Descartes, Paris, France
}

\begin{abstract}
This study concerned about threatened self-esteem and prejudice that could appear in the form of behavior of avoiding minority groups. The hypothesis of this study were that participants whose self-esteem were threatened would show (1) avoidance behavior against any minority group target (i.e. Chinese group); and (2) less willingness to spend time to interact with them. This study involved 60 female students in Bandung, aged 18-20 years. They were Sundanese people, who belonged to the majority group. In this experimental study, they received feedbacks toward the results of intelligence test, either positive or negative. Then, they were expected to interact with the target group (Chinese) or with the majority group (Sundanese). The results confirmed the hypothesis 1 , $t(28)=5.245 p<.05$; and did not confirm the hypothesis 2 .

Keywords: avoidance behavior, experimental study, prejudice, stereotyping, threatened self-esteem
\end{abstract}

Abstrak. Penelitian ini berkaitan dengan self-esteem terancam dan prasangka, yang bisa muncul dalam bentuk perilaku menghindar dari kelompok minoritas. Hipotesis yang diajukan adalah bahwa partisipan dengan self-esteem terancam akan menunjukkan: (1) perilaku lebih menghindar dari kelompok minoritas (yaitu beretnis Tionghoa), dan (2) sedikit kesediaan (willingness) untuk berinteraksi dengan mereka. Penelitian ini melibatkan 60 mahasiswi di Bandung, berusia 18-20 tahun. Mereka beretnis Sunda yang dipandang sebagai kelompok mayoritas. Dalam penelitian eksperimen ini, mereka menerima umpan balik terhadap hasil tes intelegensi rekaan, positif atau negative. Setelahnya mereka diminta untuk berinteraksi dengan target, yang tergabung pada kelompok minoritas (beretnis Tionghoa) atau pada kelompok majoritas (beretnis Sunda). Hasil penelitian memberi konfirmasi pada hipotesis 1, $t(28)=5,245 \quad p<.05$; dan tidak memberi konfirmasi pada hipotesis 2.

Kata kunci: perilaku menghindar, prasangka, self-esteem terancam, stereotyping, penelitian eksperimental

Menurut Allport (1954), prasangka (prejudice), merupakan sikap (attitude) negatif yang diarahkan suatu kelompok atau kepada seseorang, yang didahului

1,2 Korespondensi mengenai artikel ini dapat dilakukan melalui: wilis_bandung@yahoo.com, davidardes@gmail.com

3 Atau melalui: rasyid.sanitioso@parisdescartes.fr adanya suatu stereotip atau pra-penilaian terhadap kelompok tersebut. Stereotip merupakan suatu kepercayaan yang didasari oleh informasi yang tidak akurat, yang diterapkan terhadap anggota kelompok tertentu tanpa pengecualian (Myers, 2005). Prasangka yang paling umum dalam konteks kemasyarakatan adalah prasangka 
rasial dan prasangka jender. Prasangka rasial, dikenal juga sebagai prasangka etnis, merupakan prasangka yang terkait dengan sikap seseorang terhadap orang lain yang dipandang sebagai anggota dari kelompok etnis tertentu. Prasangka jender membahas tentang pemikiran peran sosial wanita dan pria dalam masyarakat (Myers, 2005). Prasangka etnis (ethnic prejudice) merupakan suatu antipati yang didasarkan atas generalisasi yang tidak benar (faulty) dan tidak fleksibel. Prasangka etnis dapat dirasakan saja oleh seseorang, namun dapat pula diekspresikan. Prasangka etnis dapat diarahkan kepada satu kelompok secara keseluruhan, atau kepada individu karena yang bersangkutan merupakan anggota kelompok yang menjadi target prasangka (lihat Allport, 1954). Prasangka memiliki beberapa ciri berikut ini: (1) Merupakan fenomena antar kelompok. Pada prasangka senantiasa terdapat kecenderungan untuk membandingkan satu kelompok dengan kelompok lainnya, atau memberi penilaian berdasarkan keanggotaan seseorang pada kelompok tertentu. (2) Merupakan orientasi negatif. Prasangka selalu mengandung pernyataan melawan (against atau opposed) sesuatu. (3) Dianggap memiliki konotasi kurang baik. Prasangka dianggap kurang sesuai dengan norma-norma berpikir umumnya, contohnya kaku (rigid) atau generalisasi yang berlebihan (over generalization), dan (4) Dikaitkan dengan sikap (attitude). Prasangka merupakan struktur yang melibatkan aspek emosi, kognitif dan perilaku, yang bertahan lama namun dapat saja berubah setelah seseorang memiliki pengalaman tertentu.

Menurut Myers (2005), prasangka dapat terbentuk atau disebabkan oleh hal berikut ini: (1) Kondisi-kondisi struktural masyarakat seperti status sosial yang tidak setara/ketidak-adilan sosial, sosialisasi atau institusi sosial. Namun demikian penelitian-penelitian terbaru tentang prasangka menunjukkan bahwa prasangka dapat pula dipicu ketika kondisi hargadiri (self-esteem) seseorang mendapatkan ancaman. Hal ini telah diperlihatkan oleh penelitian Fein dan Spencer (1997), Sinclair dan Kunda (2000), Collange, Benbouzyane, dan Sanitioso (2006), dan (2) Motivasi. Menurut Myers (2005) prasangka dapat bersumber pada: (1) Frustrasi dan agresi, atau teori 'kambing hitam'. Teori ini menjelaskan bahwa prasangka terjadi karena dibutuhkan seseorang sebagai bentuk penyaluran frustrasi yang dialaminya. Frustrasi ini akan mendorong seseorang untuk berlaku agresif sebagai upaya pengalihan rasa frustrasinya. Frustrasi akan diarahkan pada sekelompok orang yang dipandang berbeda dari masyarakat kebanyakan, yang disebut 'kambing hitam'. Keputusan mayoritas untuk menetapkan 'kambing hitam' ini yang menandai adanya prasangka. (2) Perasaan superior terhadap lainnya atau teori identitas sosial. Dari sudut pandang teori ini, seseorang mengidentifikasikan dirinya sebagai bagian dari kelompok tempatnya bergabung. Seseorang berupaya membedakan kelompoknya dengan kelompok lain melalui prasangka yang menguntungkan kelompoknya, dengan cara mengemukakan bahwa kelompoknya lebih superior dibandingkan dengan kelompok lainnya, dan (3) Motivasi menghindari prasangka. Ketika pikiran-pikiran yang tidak dikehendaki berkembang pada diri seseorang, maka secara otomatis akan timbul dorongan untuk menekan pikiran-pikiran tersebut. Tindakan untuk menekan pikiran yang tidak diinginkan tersebut disebabkan oleh perasaan bersalah pada diri seseorang. Dengan demikian ketika dalam diri seseorang telah berkembang prasangka, maka yang bersangkutan akan merasa bersalah sebab prasangka bukanlah sesuatu yang 
dianggap baik, mengingat prasangka adalah hal yang tidak diinginkan. Selanjutnya akan timbul upaya yang bersangkutan untuk menekan, mereduksi atau menghilangkan prasangka tersebut. Hal inilah yang dikatakan sebagai motivasi untuk menghindari prasangka.

Prasangka biasanya diukur dengan menilai kepercayaan seseorang tentang kelompok tertentu yang disebut stereotip. Pengukuran prasangka dilakukan secara tertulis, atau melalui perilaku non-verbal yang ditampilkan seseorang terhadap objek atau target dari prasangka tersebut.

Beberapa penelitian memperlihatkan bahwa harga-diri (self-esteem) merupakan suatu bahasan yang penting untuk dikembangkan dalam kaitannya dengan prasangka dan stereotyping, contohnya penelitian Hughes dan Demo (1989, dalam Flynn, 2003). Mengikuti pendapat Rosenberg (1965), harga-diri (self-esteem) merupakan suatu evaluasi positif ataupun negatif terhadap diri sendiri (self). Dengan kata lain harga-diri (self-esteem) adalah bagaimana seseorang memandang dirinya sendiri. Harga-diri (self-esteem) global adalah sikap positif atau negatif seseorang akan dirinya secara keseluruhan. Hargadiri (self-esteem) juga dapat berhubungan dengan dimensi spesifik, seperti kemampuan akademik, kecakapan sosial, penampilan fisik, atau harga-diri (self-esteem) kolektif, yaitu evaluasi akan kebernilaian suatu kelompok, dimana seseorang menjadi anggotanya. Termasuk dalam harga-diri (self-esteem) kolektif ini adalah kelompok etnis atau kelompok agama.

Harga diri (self-esteem) dipandang sebagai salah satu aspek penting dalam pembentukan kepribadian seseorang. Manakala seseorang tidak dapat menghargai dirinya sendiri, maka akan sulit baginya untuk dapat menghargai orangorang di sekitarnya. Dengan demikian harga-diri (self-esteem) merupakan salah satu elemen penting bagi pembentukan konsep diri seseorang, dan akan berdampak luas pada sikap dan perilakunya. Menurut pandangan Rosenberg (1965), dua hal yang berperan dalam pembentukan harga-diri (self-esteem), adalah reflected appraisals dan komparasi sosial (social comparisons). Mereka yang memiliki harga-diri (self-esteem) rendah diduga memiliki kecenderungan menjadi rentan terhadap depresi, penggunaan narkoba, dan dekat dengan kekerasan. Harga-diri (self-esteem) yang tinggi membantu meningkatkan inisiatif, resiliensi dan perasaan puas pada diri seseorang (Baumeister dkk., 2003; dalam Myers, 2005). Terlihat bahwa harga-diri (self-esteem) yang tinggi mencerminkan kondisi pribadi positif, yang akan memunculkan sikap yang baik dalam berinteraksi dengan orang lain. Seseorang dengan harga-diri (self-esteem) tinggi dikatakan memiliki resiliensi yang tinggi, yaitu memiliki kemampuan untuk bangkit kembali, dengan cara mengatasi tekanan yang dialami. Namun demikian, seseorang dengan harga-diri (self-esteem) tinggi bisa saja suatu saat mengalami kegagalan atau kekecewaan yang membuat harga-diri (self-esteem) mereka menurun. Kondisi inilah yang dikenal sebagai hargadiri (self-esteem) yang terancam. Pada kondisi tersebut harga-diri (self-esteem) dapat mengalami penurunan. Ancaman terhadap harga-diri (self-esteem) ini kemudian memunculkan reaksi untuk mempertahankan diri, yang menurut Heatherton dan Vohs (2000; dalam Myers, 2005) dapat dilakukan dengan memandang rendah orang lain dan melebih-lebihkan keunggulan mereka atas diri orang lain (lihat Myers, 2005). Reaksi tersebut sebetulnya merupakan upaya seseorang untuk mempertahankan harga-diri (self-esteem) dari hal-hal yang mengancam atau hal-hal yang dapat menurunkan harga-diri (self- 
esteem). Situasi dimana seseorang berupaya untuk mempertahankan harga-diri (selfesteem) ini dikenal dengan self-esteem maintenance. Mereka yang merasa hargadirinya (self-esteem) terancam, akan memandang kesuksesan orang lain sebagai sesuatu yang mengancam keberadaan atau keberhargaan diri mereka. Perasaan terancam ini akan menimbulkan reaksi untuk 'menjatuhkan' orang lain, apakah dengan memandang rendah orang lain atau bahkan dengan menggunakan kekerasan.

Berikut ini beberapa penelitian tentang harga-diri (self-esteem) dalam kaitannya dengan prasangka dan stereotyping. Fein dan Spencer (1997) dalam penelitiannya memberi umpan balik kepada partisipan setelah mereka menyelesaikan tes intelegensi rekaan yang diberikan. Partisipan menerima salah satu dari dua jenis umpan balik yang digunakan, yaitu; (1) umpan balik negatif, merupakan umpan balik yang mengancam diri (self) partisipan, (2) umpan balik positif, merupakan umpan balik yang tidak mengancam diri (self) partisipan. Setelah umpan balik diberikan, partisipan diminta untuk menilai atau mengevaluasi orang lain (berikutnya disebut target). Target tersebut tergolong dalam kelompok dengan stereotip negatif atau kelompok tidak dengan stereotip negatif. Hasil penelitian memperlihatkan bahwa partisipan yang menerima umpan balik negatif, akan memberikan penilaian yang lebih negatif atau lebih buruk terhadap kelompok dengan stereotip negatif, jika dibandingkan dengan partisipan yang menerima umpan balik positif. Hasil penelitian ini menunjukkan bahwa ketika partisipan merasa dirinya (self) terancam, yang dalam penelitian ini dikarenakan menerima umpan balik negatif, maka partisipan akan memberikan penilaian yang lebih negatif atau lebih buruk terhadap kelompok dengan stereotip negatif.
Hal ini jika dibandingkan dengan partisipan yang dirinya (self) tidak merasa terancam, yaitu partisipan yang memandang dirinya positif, yang dalam penelitian ini dibuat dengan cara menerima umpan balik positif. Menurut peneliti, temuan empiris tersebut menjelaskan bahwa dengan memberi kesempatan partisipan untuk memberikan penilaian negatif atau buruk terhadap target, partisipan yang sebelumnya merasa dirinya (self), yaitu harga-dirinya (self-esteem) atau citradiri (self-image) telah terancam, dapat mengembalikan atau memulihkan hargadirinya (self-esteem) atau citra-dirinya (selfimage) seperti semula atau pada tingkat yang dapat mereka terima, yaitu pada titik di mana ia merasa 'aman', tidak terancam. Partisipan yang tidak mendapatkan kesempatan untuk memberikan penilaian negatif atau buruk terhadap target setelah mereka merasa dirinya (self) terancam melalui penerimaan umpan balik negatif, tetap memperlihatkan harga-diri (selfesteem) atau citra-diri (self-image) yang rendah. Dari hasil penelitian tersebut disimpulkan bahwa ancaman terhadap diri (self), yaitu harga-diri (self-esteem) atau citra-diri (self-image), dapat memunculkan prasangka dan stereotyping. Prasangka dan stereotyping, dengan demikian dapat ditimbulkan oleh kebutuhan seseorang untuk mengatasi perasaan terancam yang dialami dirinya (self). Stereotyping dalam hal ini dimengerti sebagai memperlakukan orang lain, yaitu target, bukan sebagai diri yang autentik dan memiliki kekhasan, melainkan lebih dilihat sebagai anggota sebuah kelompok dan dengan demikian memiliki ciri kelompok tersebut.

Dalam penelitian Sinclair dan Kunda (2000), partisipan penelitian yang dalam hal ini berjenis kelamin pria, diberi umpan balik oleh manajer wanita. Hasil penelitian memperlihatkan bahwa partisipan yang 
menerima umpan balik negatif tentang keterampilan interpersonal mereka dari manajer wanita, cenderung memberi penilaian negatif terhadap sang manajer. Hal ini jika dibandingkan dengan partisipan yang menerima umpan balik positif tentang keterampilan yang sama dari manajer yang juga wanita. Namun demikian ketika umpan balik diterima dari manajer pria, partisipan yang menerima umpan balik negatif dan penerima umpan balik positif, memperlihatkan hasil yang tidak berbeda. Bertolak dari hasil penelitian tersebut, peneliti menyimpulkan bahwa kebutuhan untuk memulihkan diri (self-esteem atau self-image) yang terancam dapat mengarah pada peningkatan prasangka dan stereotyping.

Collange dkk. (2006) bertempat di Paris, Perancis, melanjutkan dan mengembangkan penelitian Fein dan Spencer (1997). Penelitian dilakukan terhadap partisipan beretnis Perancis. Hal yang hendak diketahui adalah konsekuensi perilaku dari prasangka dan stereotyping setelah partisipan merasa harga-dirinya (selfesteem) terancam. Konsekuensi perilaku yang dimaksud adalah perilaku menghindar atau menjauh dari target (lihat Macrae, Bodenhausen, Milne, \& Jetten, 1994). yang dalam hal ini berasal dari etnis Arab. Penggunaan etnis Arab dalam penelitian ini dipilih dengan pertimbangan bahwa etnis Arab merupakan etnis minoritas di Perancis dan sering menerima stereotip negatif (Boëldieu \& Borrel, 2000, dalam Collange dkk., 2006). Dalam penelitian eksperimen yang dilakukan, partisipan diminta untuk menyelesaikan tes intelegensi rekaan yang diberikan. Setelah itu umpan balik positif maupun negatif, disampaikan kepada partisipan. Partisipan kemudian diminta untuk menempati kursi yang telah ditata sedemikan rupa. Perilaku menghindar dari partisipan di sini diketa- hui dari jarak antara kursi yang mereka duduki dengan kursi yang diduduki target. Dalam penelitian ini targetnya adalah orang beretnis Perancis (sebagai etnis majoritas di Negara Perancis) atau beretnis Arab (sebagai etnis minoritas di negara Perancis). Hasil penelitian menunjukkan bahwa partisipan penerima umpan balik negatif dari hasil tes intelegensi rekaan, memperlihatkan perilaku menghindar yang lebih besar terhadap target beretnis Arab. Hal ini terlihat dari jarak yang lebih jauh antara kursi yang diduduki partisipan dengan kursi target beretnis Arab, dibandingkan dengan jarak antara kursi partisipan dengan kursi targe beretnis Perancis. Keadaan ini memperlihatkan bahwa partisipan yang merasa harga-dirinya (self-esteem) terancam, yang dalam penelitian ini adalah partisipan penerima umpan balik negatif dari hasil tes intelegensi rekaan, menunjukkan perilaku menghindar yang lebih besar terhadap target berstereotip negatif (dalam penelitian ini beretnis Arab). Temuan empiris tersebut memberi konfirmasi terhadap penelitian yang dilakukan sebelumnya oleh Fein dan Spencer (1997), serta Sinclair dan Kunda (2000). Meskipun hasil penelitian tersebut terlihat sejalan dan saling mengkonfirmasi, namun penelitian serupa masih diperlukan dengan partisipan penelitian yang berbeda (Collange dkk., 2006). Temuan empiris ini dibutuhkan untuk melihat apakah hal yang sama juga terdapat pada populasi yang berbeda dan lebih luas. Melalui temuan tersebut hasil konseptual yang telah diperoleh pada penelitian-penelitian sebelumnya mendapatkan penegasan.

Pada tulisan ini hendak disampaikan hasil penelitian yang merupakan kelanjutan dari penelitian Collange, dkk. (2006) di Paris, Perancis, yang hasilnya perlu ditinjau dalam populasi yang lebih luas. 
Penelitian dilakukan di Bandung, dan bermaksud melihat pengaruh harga-diri (self-esteem) yang terancam terhadap perilaku menghindar (avoidance), yang merupakan bagian dari hierarki tindak prasangka (Allport, 1954). Perilaku menghindar yang dimaksud dalam penelitian ini adalah perilaku menghindar dari target. Target dalam penelitian ini adalah etnis Tionghoa, yang merupakan kelompok minoritas di Bandung, dan etnis Sunda yang merupakan kelompok mayoritas di Bandung.

Merujuk pada pendapat Sindhunata (2006), etnis Tionghoa di Indonesia dimengerti sebagai sekumpulan sub-etnis dari bangsa Tionghoa yang terdiri dari etnis Hakka, Hokkian, Hainan, Kantonis, Hokchia, Tiochiu. Oleh karena sub-etnis tersebut tidak dikenal secara luas oleh masyarakat Indonesia, maka mereka semua dikenal sebagai "orang Tionghoa". Pengertian etnis Tionghoa inilah yang dijadikan dasar dalam penelitian ini. Perkiraan kasar yang dipercaya mengenai jumlah suku Tionghoa-Indonesia saat ini ialah berada di antara kisaran $4 \%$ - 5\% dari seluruh jumlah populasi Indonesia (Turner \& Allen, 2007).

Etnis Sunda adalah penduduk asli di Provinsi Jawa Barat dan merupakan penduduk terbesar di Jawa Barat. Dalam perkembangannya, istilah Sunda digunakan juga dalam konotasi manusia atau sekelompok manusia, yaitu dengan sebutan 'urang Sunda' yang artinya adalah 'orang Sunda'. Dalam definisi tersebut tercakup sekaligus dua kriteria, yaitu berdasarkan keturunan atau hubungan darah, dan berdasarkan sosial budaya. Menurut kriteria pertama, seseorang bisa disebut orang Sunda, jika salah satu atau kedua orang tuanya adalah orang Sunda, di mana pun mereka berada dan dibesarkan. Menurut kriteria kedua, orang
Sunda adalah orang yang dibesarkan dalam lingkungan sosial budaya Sunda dan dalam hidupnya menghayati serta mempergunakan norma-norma dan nilainilai budaya Sunda (lihat Setiady, 2010). Yang dimaksud dengan etnis Sunda pada penelitian ini adalah partisipan yang memenuhi kedua kriteria tersebut.

Penelitian yang dilaporkan kali ini adalah penelitian utama yang merupakan ujung dari serangkaian penelitian, yaitu: (1) Penelitian eksploratif untuk melihat kecenderungan prasangka terhadap etnis Tionghoa di kalangan mahasiswa. Penelitian ini dilakukan dalam rangka pemilihan etnis Tionghoa sebagai target dalam penelitian (Setiady, 2010). (2) Adaptasi Rosenberg Self-Esteem Scale dari Morris Rosenberg (1965). Luaran yang diperoleh berupa versi bahasa Indonesia The Rosenberg Self-Esteem Scale (RSES) dari Morris Rosenberg (1965), dengan konsistensi internal Cronbach $\alpha=.76$ (lihat Setyadi, 2010). Adaptasi lebih diarahkan untuk kepentingan state self-esteem daripada trait self-esteem. (3) Penelitian eksperimental dalam rangka melihat apakah pemberian ancaman melalui pemberian umpan balik negatif berpengaruh terhadap harga-diri (self-esteem). Penelitian dilakukan oleh Setiady (2010) terhadap 22 mahasiswi di Bandung yang berpartisipasi secara sukarela. Mereka beretnis Sunda dan berusia 18-20 tahun ( $M=18,55 ; S D=0,8)$. Prosedur pengambilan data pada penelitian ini mengikuti prosedur yang diterapkan Collange dkk. (2006) pada penelitian mereka untuk mendapatkan materi eksperimen, yang diikuti secara sukarela oleh 24 mahasiswa dan mahasiswi semester pertama yang berbahasa ibu Perancis, berusia 18-25 tahun. Prosedur yang dilakukan oleh Collange dkk. (2006) dalam penelitian tersebut adalah sebagai berikut: (1) Partisipan diberi informasi bahwa mereka akan 
mengikuti penelitian mengenai validasi tes intelegensi di Negara Perancis. Tujuan penelitian tersebut adalah untuk melakukan komparasi hasil tes dari populasi mahasiswa dengan latar-belakang berbeda. Tes tersebut telah diberikan kepada mahasiswa Fakultas Kedokteran. Pemberian skor terhadap hasil tes akan dilakukan menggunakan komputer, sehingga hasil tes dapat segera diketahui. (2) Partisipan diminta mengerjakan tes yang berisi 20 soal tersaji dalam bentuk buku, seakurat dan secepat mungkin. (3) Setelah tes selesai dikerjakan, eksperimenter mengumpulkan lembar jawaban, membawanya keluar ruangan selama beberapa menit untuk mengesankan bahwa jawaban sedang diskor oleh komputer. (4) Eksperimenter memasuki ruangan kembali dengan membawa lembar skor. (5) Disampaikan kepada partisipan bahwa 55\% jawaban mereka benar. (6) Disampaikan kepada 8 partisipan bahwa skor yang mereka peroleh sama dengan skor mahasiswa Fakultas Kedokteran berbahasa ibu Perancis, kepada 8 partisipan bahwa skor yang mereka peroleh lebih rendah dari skor mahasiswa Fakultas Kedokteran berbahasa ibu Perancis, dan kepada 8 partisipan bahwa skor yang mereka peroleh lebih tinggi dari skor mahasiswa Fakultas Kedokteran berbahasa ibu Perancis. (7) Partisipan mengisi The Rosenberg SelfEsteem Scale (RSES). Hasil penelitian Setiady (2010) memperlihatkan adanya tendensi bahwa pemberian umpan balik memengaruhi kondisi harga-diri (selfesteem) seseorang. Hal ini bergantung kepada jenis umpan balik, yaitu apakah umpan balik tersebut menyatakan keberhasilan seseorang (umpan balik positif), atau sebaliknya menyatakan kegagalan seseorang (umpan balik negatif), bila dibandingkan dengan pencapaian orang lain. Dibandingkan dengan kelompok kontrol, yaitu partisipan yang menerima umpan balik netral (pencapaiannya sama dengan pencapaian orang lain), partisipan yang menerima umpan balik negatif memperlihatkan harga-diri (self-esteem) yang relatif rendah dalam skala Rosenberg, dibandingkan dengan partisipan yang menerima umpan balik positif. Disimpulkan bahwa ancaman terhadap harga-diri (selfesteem), yang dalam hal ini adalah pemberian umpan balik negatif, dapat menurunkan harga-diri (self-esteem) seseorang, yang dalam hal ini diukur melalui skala Rosenberg. Melalui aktivitas ini diperoleh pula informasi bahwa manipulasi berbentuk ancaman terhadap harga-diri (selfesteem) dapat disampaikan melalui pemberian umpan balik rekaan bersifat negatif terhadap hasil tes intelegensi rekaan. Umpan balik dilakukan dengan cara membandingkan skor rekaan yang diperoleh partisipan dengan skor rekaan partisipan lain, yang dalam hal ini adalah mahasiswa Fakultas Kedokteran. Luaran lain dari penelitian ini adalah protokol eksperimen, berkenaan dengan manipulasi yang dilakukan dalam rangka memberikan ancaman terhadap harga-diri (self-esteem), melalui pemberian umpan balik rekaan bersifat negatif terhadap hasil tes inteligensi rekaan. Protokol eksperimen yang telah dikembangkan oleh Setiady (2010) tersebut, diterapkan pada eksperimen yang dilaporkan pada penelitian ini.

\section{Metode}

\section{Variabel independen}

Pemberian umpan balik terhadap hasil tes intelegensi rekaan. Umpan balik positif diberikan dengan menyampaikan bahwa hasil tes partisipan lebih tinggi dari rata-rata hasil tes mahasiswa Fakultas Kedokteran dari universitas yang sama. Umpan balik negatif diberikan dengan menyampaikan bahwa hasil tes partisipan 
lebih rendah dari rata-rata hasil tes mahasiswa Fakultas Kedokteran dari universitas yang sama.

Variabel dependen tahap 1: Perilaku lebih menghindar dari target. Diukur melalui jarak fisik antara kursi yang ditempati oleh partisipan dengan kursi yang ditempati oleh target.

Variabel dependen tahap 2: Kesediaan (willingness) untuk berinteraksi dengan target.

Diukur dari lamanya waktu yang disediakan partisipan untuk dihabiskan bersama dengan target.

\section{Partisipan penelitian}

Partisipan penelitian adalah 60 mahasiswi di Bandung, berusia 18-20 tahun $(M=19,2 ; S D=0,81)$. Mereka beretnis Sunda, sebagai kelompok etnis mayoritas, dan berpartisipasi secara sukarela.

\section{Prosedur}

1) Satu per satu partisipan diminta memasuki ruangan dan disilakan duduk. Mereka diberi informasi bahwa penelitian yang akan dilangsungkan berkenaan dengan dua hal, yaitu: (a) Penelitian pertama atau penelitian 1 merupakan penelitian tentang persepsi spasial dalam rangka melakukan validasi terhadap tes intelegensi. (b) Penelitian ke dua, atau penelitian 2 merupakan penelitian tentang interaksi antara dua orang atau diadik. Lalu mereka diminta membubuhkan tanda tangan pada lembar persetujuan.

2) Penelitian 1 dilakukan oleh eksperimenter 1.

Partisipan diminta untuk menyelesaikan tes intelegensi sesuai dengan instruksi yang diberikan. Prosedur pengambilan data pada penelitian 1 mengikuti prosedur yang telah dikem- bangkan oleh Setiady (2010). Setelah selesai, partisipan menerima umpan balik rekaan terhadap hasil tes mereka, berupa umpan balik positif (30 partisipan) atau umpan balik negatif (30 partisipan). Kemudian mereka mengikuti Penelitian 2, dengan variabel dependen tahap 1.

3) Penelitian 2 dilakukan oleh eksperimenter 2.

Eksperimenter 2 tidak mengetahui (blind) terhadap jenis umpan balik yang diterima partisipan dalam penelitian 1, apakah umpan balik positif atau umpan balik negatif. Partisipan diberitahu bahwa penelitian 2 segera dimulai. Partisipan diminta mengisi lembar biodata. Setelah biodata dikumpulkan, eksperimenter 2 meninggalkan ruangan selama beberapa saat.

4) Eksperimenter 2 memasuki ruangan kembali dengan membawa lembar biodata terisi dari partisipan fiktif, berisi nama, berjenis kelamin perempuan, tempat dan tanggal lahir, latar belakang etnis (Tionghoa atau Sunda), hobi, asal fakultas dan semester yang sedang dijalani. 30 partisipan menerima biodata partisipan fiktif beretnis Tionghoa, 30 partisipan menerima biodata partisipan fiktif beretnis Sunda.

5) Partisipan diminta untuk mengerjakan satu tugas, dengan bekerja sama dengan partisipan lain bertempat di ruang yang berbeda. Tidak disampaikan bahwa partisipan tersebut sebenarnya fiktif. Eksperimenter 2 mengantar partisipan memasuki ruang lainnya, dan berlaku sedemikian rupa sehingga partisipan memasuki ruangan terlebih dahulu, diikuti oleh eksperimenter 2. Dalam ruangan tersebut terdapat kursi yang ditata berjejer. Kursi pertama ditandai sedemikian rupa untuk mengesankan bahwa kursi tersebut telah 
ditempati oleh partisipan fiktif. Partisipan penelitian dipersilakan untuk memilih tempat duduknya dari kursi yang tersisa. Ini merupakan pengukuran variabel dependen tahap 1.

6) Setelah partisipan menduduki kursi yang dipilihnya, partisipan diminta menuliskan waktu yang mereka sediakan untuk berinteraksi bersama partisipan fiktif. Ini merupakan pengukuran variabel dependen tahap 2 .

7) Debriefing.

Pengukuran, pemberian skor dan analisis

Variabel dependen tahap 1, yaitu perilaku menghindar partisipan dari target, pada penelitian ini diukur melalui jarak fisik antara kursi yang ditempati oleh partisipan dengan kursi yang ditempati oleh target. Pada ruangan pengukuran, ditata 6 kursi yang diletakkan berjejer. Jarak satu kursi dengan kursi lainnya adalah $30 \mathrm{~cm}$. Pada kursi pertama terdapat tas ransel, yang mengindikasikan bahwa kursi tersebut telah ditempati oleh partisipan fiktif. Partisipan penelitian dipersilakan untuk memilih tempat duduknya, dari 5 kursi tersisa.

Skor 0 diberikan jika partisipan memilih kursi yang terletak tepat di sebelah kursi partisipan fiktif, yaitu kursi ke dua. Ini adalah jarak yang terdekat. Skor 4 diberikan jika partisipan memilih kursi yang terjauh letaknya dari kursi partisipan fiktif, yaitu kursi ke enam. Perhitungan dilakukan untuk mengetahui jarak ratarata dari empat kelompok penelitian, yaitu kelompok yang menerima umpan balik positif (dengan target beretnis Tionghoa atau beretnis Sunda) dan kelompok yang menerima umpan balik negatif (dengan target beretnis Tionghoa atau beretnis Sunda), dan dianalisis dengan mengguna- kan anova dilanjutkan dengan uji $t$ untuk setiap pasangan kondisi.

Variabel dependen tahap 2, yaitu lamanya waktu yang disediakan partisipan untuk dihabiskan bersama target, diukur melalui jumlah menit yang dituliskan partisipan. Perhitungan dilakukan terhadap waktu rata-rata dari empat kelompok penelitian, yaitu kelompok yang menerima umpan balik positif (dengan target beretnis Tionghoa atau beretnis Sunda) dan kelompok yang menerima umpan balik negatif (dengan target beretnis Tionghoa atau beretnis Sunda), dan dianalisis dilakukan dengan menggunakan anova dilanjutkan dengan uji $t$ untuk setiap pasangan kondisi.

\section{$\mathrm{H}$ a $\mathrm{s}$ i 1}

Pertama kali akan disajikan hasil penelitian dengan variable dependen tahap 1, yang merupakan tujuan utama, yaitu untuk melihat apakah harga-diri (self-esteem) terancam yang dialami seseorang akan memunculkan perilaku menghindar dari target berlatar-belakang etnis minoritas. Hasilnya merupakan pengukuran terhadap selisih jarak bangku antara partisipan terhadap partisipan fiktif, baik yang etnis Tionghoa maupun etnis Sunda. Jarak bangku menjadi indikator timbulnya perilaku menghindar pada partisipan, semakin jauh jarak yang terdapat antara partisipan dan partisipan fiktif maka dapat diartikan bahwa partisipan menghindar dari partisipan. Perbedaan jarak yang ditimbulkan antara partisipan dengan etnis Tionghoa dan etnis Sunda mengindikasikan adanya perilaku diskriminatif (lihat Allport, 1954).

Hasil penelitian dengan variabel dependen tahap 1 memperlihatkan bahwa pemberian umpan balik berpengaruh terhadap perilaku menghindar dari target, 
$F(3,42)=12.799, p<.01, \eta^{2}=.48$. Hasil dari effect size (eta squared) menunjukkan $48 \%$ variabilitas jarak disebabkan oleh perbedaan empat kondisi (umpan balik negatif dan positif, target beretnis Tionghoa dan Sunda).

Selanjutnya melalui uji $t$ terhadap pasangan setiap kondisi diperoleh hasil bahwa partisipan yang menerima umpan balik negatif memilih tempat duduk yang jaraknya secara signifikan lebih jauh dari tempat duduk target beretnis Tionghoa, yang dalam penelitian ini adalah partisipan fiktif beretnis Tionghoa, $(M=2,4$; $S D=0,91)$, dibandingkan dengan jarak tempat duduk mereka dari tempat duduk target beretnis Sunda, yang dalam penelitian ini adalah partisipan fiktif beretnis Sunda $(M=0,67 ; S D=0,9), t(14)=4,67 ; p<.01$. Sebaliknya partisipan yang menerima umpan balik positif memilih tempat duduk yang jaraknya lebih dekat dari tempat duduk target beretnis Tionghoa, yang dalam penelitian ini adalah partisipan fiktif beretnis Tionghoa $(M=0,73 ; S D=0,594)$, dibandingkan dengan jarak tempat duduk mereka dari tempat duduk target beretnis Sunda, yang dalam penelitian ini adalah partisipan fiktif beretnis Sunda $(M=1,13$; $S D=0,743)$, meskipun tidak signifikan, $t(14)=-1,468 ; p=0, .164$; ns. Dalam menghadapi target beretnis Tionghoa, partisipan yang menerima umpan balik negatif tersebut juga memilih tempat duduk yang jaraknya secara signifikan lebih jauh $(M=2,4$; $S D=0,91)$ jika dibandingkan dengan partisipan yang menerima umpan balik positif $(M=0,73 \quad S D=0,59), \quad t(14)=5,801 ; \quad p<.01$. Ketika menghadapi target beretnis Sunda, partisipan yang menerima umpan balik negatif tersebut memilih tempat duduk yang jaraknya lebih dekat $(M=0,67$; $S D=0,9)$ jika dibandingkan dengan partisipan yang menerima umpan balik positif $(M=1,13 \quad S D=0,743)$, walaupun secara statistik tidak signifikan, $t(14)=-1.388 ; p=$ 0.187 ; ns.

Berikutnya adalah hasil penelitian dengan variable dependen tahap 2, yaitu lamanya waktu yang disediakan partisipan untuk dihabiskan bersama target. Hasilnya memperlihatkan bahwa pemberian umpan balik berpengaruh terhadap lamanya waktu yang disediakan partisipan untuk dihabiskan bersama target, $F(3,42)=5.801, p<.01, \eta^{2}=.29$. Hasil dari effect size (eta squared) menunjukkan 29\% variabilitas lamanya waktu disebabkan oleh perbedaan empat kondisi (umpan balik negatif dan positif, target beretnis Tionghoa dan Sunda).

Hasil analisis melalui uji $t$ terhadap pasangan setiap kondisi menunjukkan bahwa bersama target beretnis Tionghoa, partisipan yang menerima umpan balik negatif akan menghabiskan waktu mereka secara signifikan lebih lama $(M=12,13$ menit; $S D=4,969$ menit) dibandingkan dengan partisipan yang menerima umpan balik positif $(M=5,8$ menit; $S D=2,569$ menit), $t(14)=, 385 ; p=4,083 ; p<.01$. Bersama dengan target beretnis Sunda partisipan yang menerima umpan balik positif akan menghabiskan waktu mereka lebih lama $(M=10,27$ menit; $S D=4,906$ menit) dibandingkan dengan partisipan yang menerima umpan balik negatif ( $M=8,67$ menit; $S D=3,039$ menit), namun hasil tersebut secara statistik tidak signifikan, $t(14)=$ -0.95; $p=0,358$; ns. Hasil penelitian memperlihatkan pula bahwa partisipan yang menerima umpan balik positif akan menghabiskan waktu mereka secara signifikan lebih lama bersama dengan target beretnis Sunda ( $M=10,27$ menit; $S D=4,906$ menit) dibandingkan dengan bersama target beretnis Tionghoa $(M=5,8$ menit; $S D=2,569$ menit), $t(14)=-3,522 ; p=0,003 ; p<.01$. Partisipan yang menerima umpan balik negatif akan menghabiskan waktu mereka secara 
signifikan lebih lama bersama dengan target beretnis Tionghoa ( $M=12,13$ menit; $S D=4,969$ menit) dibandingkan dengan target beretnis Sunda $(M=8,67$ menit; $S D=3,039$ menit, $t(14)=2,225 ; p=0,043$; $p<.05$.

\section{Diskusi}

Hasil penelitian terkait dengan tujuan utama, yaitu hasil penelitian dengan variable dependen tahap 1, memberi konfirmasi terhadap prediksi yang telah dinyatakan sebelumnya dalam hipotesis, yaitu bahwa partisipan yang harga-dirinya (self-esteem) merasa terancam memperlihatkan perilaku menghindar dari target yang berasal dari kelompok minoritas dengan stereotip negatif. Pada penelitian ini partisipan yang merasa harga-dirinya (self-esteem) terancam, yaitu partisipan yang menerima umpan balik negatif atas pengerjaan tes intelegensi, lebih menunjukkan perilaku menghindar terhadap target beretnis Tionghoa, dibandingkan jika mereka dihadapkan pada target beretnis Sunda, sama dengan etnis mereka. Hal ini sesuai dengan pendapat Heatherton dan Vohs (2000; dalam Myers, 2005), bahwa ancaman terhadap harga-diri (self-esteem) seseorang dapat memunculkan reaksi untuk mempertahankan harga diri (self-esteem maintenance). Reaksi dilakukan antara lain dengan cara memandang rendah orang lain (lihat Myers, 2005), atau menghindar dari target (lihat Allport, 1954). Reaksi tersebut sebetulnya merupakan upaya seseorang untuk mempertahankan harga-diri (self-esteem) dari hal-hal yang mengancam atau hal-hal yang dapat menurunkan harga-diri (selfesteem). Dengan demikian dapat disimpulkan bahwa hasil penelitian ini memberi konfirmasi pada temuan yang diperoleh Fein dan Spencer (1997), Sinclair dan Kunda (2000), Collange dkk. (2006).
Partisipan penelitian adalah mahasiswa yang waktunya lebih banyak dihabiskan di lingkungan akademik (lihat Collange dkk., 2006), sehingga memiliki kecenderungan untuk menghindari prasangka dan stereotyping (lihat Myers, 2005). Oleh karenanya harus hati-hati dan penuh pertimbangan jika generalisasi hasil penelitian akan dilakukan terhadap populasi non-mahasiswa.

Hasil penelitian ini dapat berguna dalam tataran praktis, sebagaimana contoh berikut ini: (1) Hasil penelitian dapat dimanfaatkan dalam mewaspadai kondisikondisi yang diperkirakan dapat menurunkan harga-diri (self-esteem) seseorang di berbagai lingkungan, seperti di lingkungan pendidikan (sekolah), keluarga, sosial, pekerjaan, dan lain sebagainya. Dengan diketahuinya kondisi-kondisi tersebut, maka upaya pencegahan dapat dilakukan agar kondisi-kondisi yang diperkirakan dapat menurunkan harga-diri (self-esteem) tidak terjadi. (2) Hasil penelitian juga dapat memberi penyadaran bahwa lingkungan sosial Indonesia yang memiliki beragam kelompok etnis seharusnya mendapat perhatian khusus. Populasi dari setiap kelompok etnis yang tidak sama dan penyebarannya yang tidak merata di wilayah Indonesia, dapat memunculkan adanya kelompok mayoritas dan minoritas etnis di satu lingkungan sosial. Contoh dalam penelitian ini adalah kelompok beretnis Tionghoa yang menjadi minoritas di tengah kelompok mayoritas beretnis Sunda. Selain kelompok minoritas dengan stereotip positif, kelompok minoritas dengan stereotip negatif juga dapat berkembang dalam kondisi tersebut, yang selanjutnya dapat menjadi cikal bakal bagi berkembangnya prasangka etnis.

Hasil penelitian dengan variabel dependen tahap 2 tidak memberikan konfirmasi terhadap hal yang diprediksikan 
dalam hipotesis, yaitu bahwa partisipan yang harga-dirinya (self-esteem) merasa terancam, yang dalam penelitian ini adalah partisipan yang menerima umpan balik negatif atas pengerjaan tes mereka, akan menunjukkan perilaku yang cenderung lebih menghindar dari target beretnis Tionghoa. Terdapat dua penjelasan terhadap hasil tersebut, yaitu: (1) Penjelasan pertama dikaitkan dengan hilangnya motivasi untuk mengembalikan atau memulihkan harga-diri (self-esteem) yang terancam. Artinya perilaku menghindar dari target, yang mengikuti perasaan terancam terhadap harga-diri (self-esteem), diasumsikan sudah dapat mengembalikan harga-diri (self-esteem) yang terancam. Setelah hargadiri (self-esteem) tidak lagi merasa terancam, maka dengan sendirinya perilaku menghindar yang dimaksudkan untuk mengembalikan harga-diri (self-esteem) tidak lagi muncul dan dapat diobservasi. Hal ini berarti bahwa perilaku partisipan selanjutnya tidak lagi didasari oleh motif untuk mengembalikan harga-diri (selfesteem) (Liberman \& Förster, 2000; Spencer dkk., 1998). Pada penelitian ini perilaku menghindar dari target beretnis Tionghoa, telah dapat atau berhasil mengembalikan harga-diri (self-esteem) partisipan yang terancam. Dengan demikian upaya untuk mengembalikan harga-diri (self-esteem) partisipan yang terancam tidak lagi mendasari motif perilaku berikutnya, yaitu saat partisipan diminta untuk menghabiskan waktunya bersama target (partisipan fiktif) beretnis Tionghoa. Dapat dimengerti jika hasil penelitian memperlihatkan bahwa partisipan bersedia menghabiskan waktunya lebih banyak dengan target beretnis Tionghoa, dibandingkan dengan target beretnis Sunda. Bersama target beretnis Tionghoa, partisipan yang menerima umpan balik negatif juga bersedia menghabiskan waktunya lebih banyak dibandingkan dengan partisipan penerima umpan balik positif. Partisipan penerima umpan balik positif bersedia menghabiskan waktunya lebih lama bersama target beretnis Sunda dibandingkan dengan target beretnis Tionghoa. (2) Penjelasan kedua berkenaan dengan munculnya motivasi untuk menghindari prasangka atau motivasi untuk mempertahankan harga-diri (self-esteem) yang egaliter. Berkaitan dengan penjelasan ini, penelitianpenelitian sebelumnya telah memperlihatkan pentingnya motivasi untuk menghindari prasangka atau mempertahankan harga-diri (self-esteem) di kalangan mahasiswa, dan bahwa motif ini dapat memunculkan perilaku koreksi yang berlebihan, atau over-correction (Dovidio dkk., 1992; Devine dkk., 2002). Melalui penjelasan tersebut, dapat diterangkan alasan partisipan bersedia menghabiskan waktu lebih lama bersama target beretnis minoritas. Setelah partisipan menunjukkan perilaku menghindar dari target beretnis minoritas, partisipan merasa bahwa perilaku tersebut tidak dapat dibenarkan dan perlu mengoreksinya melalui perilaku yang lain. Kesediaan untuk menghabiskan waktu lebih lama bersama target tersebut, boleh jadi mencerminkan motivasi untuk menghindari prasangka atau motivasi untuk mempertahankan harga-diri (self-esteem) yang egaliter. Perilaku tersebut merupakan koreksi yang berlebihan atau overcorrection terhadap perilaku sebelumnya, yaitu menghindar dari target dengan latar belakang etnis minoritas. Pada penelitian ini kesediaan partisipan untuk menghabiskan waktu bersama target beretnis Tionghoa yang lebih lama dibandingkan dengan bersama target beretnis Sunda, menunjukkan motivasi partisipan untuk menghindari prasangka atau untuk mempertahankan harga-diri (self-esteem) mereka yang egaliter. Hal ini sekaligus menjelaskan bahwa partisipan bermaksud untuk mengoreksi perilaku menghindar 
dari target beretnis Tionghoa yang dilakukan sebelumnya, melalui perilaku menghabiskan waktu bersama target beretnis Tionghoa. Dikatakan bahwa upaya koreksi tersebut dilakukan secara berlebihan atau over-correction (Dovidio dkk., 1992; Devine dkk., 2002). Hal ini diperkuat oleh hasil penelitian bahwa partisipan penerima umpan balik positif, secara signifikan bersedia menghabiskan waktu lebih lama bersama target beretnis Sunda.

Berikut ini merupakan pembahasan tentang isu-isu metodologi terkait perilaku menghindar dari target: (1) Secara konseptual dinyatakan oleh Liberman dan Förster (2000), dan Spencer dkk. (1998) bahwa motivasi untuk mengembalikan harga-diri (self-esteem) yang terancam dapat menjadi alasan meningkatnya perilaku stereotyping, diskriminatif serta menghindar. Pada penelitian ini motif untuk menghindari prasangka dilihat dari lamanya waktu yang akan dihabiskan bersama target. Secara metodologis, penjelasan secara konseptual tersebut pada penelitian ini tidak diuji secara langsung melalui perlakuan pada eksperimen. Dengan demikian hal ini merupakan salah satu keterbatasan penelitian ini. (2) Penelitian ini menggunakan dua cara pengukuran, yaitu: (a) Melalui jarak tempat duduk yang dipilih partisipan dari kursi target. Pengukuran ini sangat halus, subtil, tidak nyata, tidak banyak melibatkan kontrol sadar partisipan (lihat Hebl dkk., 2002). Melalui pengukuran ini tanda-tanda (cues) terkait prasangka tidak mengemuka secara jelas. (b) Melalui pertanyaan tentang kesediaan (the willingness) partisipan untuk menghabiskan waktu bersama target. Pengukuran melalui cara ini memerlukan kontrol penuh partisipan dan partisipan dapat mengendalikan proses pengambilan keputusan untuk menekan perilaku prasangka dan stereotyping (lihat Bargh dkk.,
1996; Blair, 2002; Hebl dkk., 2002). Hasil penelitian memperlihatkan bahwa melalui cara pertama, hipotesis penelitian mendapatkan konfirmasi, sementara melalui cara ke dua, hipotesis penelitian tidak mendapatkan konfirmasi. Bertolak dari kedua hasil tersebut dapat direkomendasikan untuk penelitian selanjutnya, agar pengukuran terhadap perilaku menghindar dari target beretnis minoritas dilakukan melalui cara yang lebih otomatis. Melalui pengukuran yang lebih otomatis, kontrol partisipan dalam upayanya menekan terjadinya prasangka dan stereotyping dapat berkurang (Plant \& Devine, 1998; Devine, 1989).

Penelitian ini tidak mempertimbangkan perbedaan individual. Setiap individu dapat memiliki tingkat prasangka yang tidak sama, sehingga motivasi untuk mengontrol prasangka dan menjauhi perilaku menghindar dari target beretnis minoritas, dapat menjadi berbeda pula (lihat Devine dkk., 2002). Dengan demikian perbedaan individual perlu dipertimbangkan pada penelitian selanjutnya. Hal ini dapat dilakukan melalui pengukuran tingkat motivasi individu untuk mengontrol atau menghindari prasangka (Devine dkk., 2002; Lepore \& Brown, 2002; Plant \& Devine, 1998; Phelps dkk., 2000).

Penelitian ini tidak mempertimbangkan afek atau emosi. Beberapa penulis membahas keterkaitan antara harga-diri (self-esteem) yang terancam dengan perilaku menghindar, berkenaan dengan afek atau emosi. Forgas dan Bower (1987, dalam Collange dkk. 2006), mengemukakan bahwa kondisi afektif yang negatif secara umum menyertai harga-diri (selfesteem) yang terancam. Semakin negatif penilaian atau evaluasi yang diberikan kepada target, semakin negatif pula kondisi afektif yang dialami oleh seseorang yang harga-dirinya (self-esteem) terancam. 
Schwarz (1990, dalam Collange dkk. 2006), memandang afek sebagai informasi. Afek sebagai informasi diprediksikan mengurangi stereotyping pada seseorang yang berada dalam kondisi afektif negatif, seperti dijumpai pada seseorang yang hargadirinya (self-esteem) terancam. Ikegami, dalam Collange dkk., 2006ł menyinggung kondisi suasana hati (mood), yang menurutnya berbeda dari kondisi afek. Temuan penting dari penelitiannya adalah bahwa harga-diri (self-esteem) terancam dapat disertai secara khusus oleh suasana hati negatif terkait dengan diri (self). Dengan demikian peran afek atau emosi, kondisi afeksi dan kondisi suasana hati seharusnya diakomodasi dalam penelitian-penelitian selanjutnya.

Hasil penelitian awal yang dilakukan Setiady (2010), dalam rangka penelitian utama yang merupakan ujung dari serangkaian penelitian eksperimental, memperlihatkan adanya penolakan terhadap hipotesis bahwa ancaman terhadap harga-diri (self-esteem) akan diikuti dengan perilaku menghindar dari target. Penelitian kali ini memberikan hasil yang sebaliknya, yaitu bahwa ancaman terhadap harga-diri (selfesteem) akan diikuti dengan perilaku menghindar dari target. Dengan hasil yang belum stabil seperti itu, maka penelitian serupa tampak masih diperlukan untuk menegaskan hasilnya, tentunya dengan penyempurnaan aspek metodologi seperti yang telah dikemukakan sebelumnya.

Penelitian-penelitian sebelumnya tentang harga diri (self-esteem) dikaitkan dengan prasangka dalam model transaksional (Major, McCoy, \& Kaiser, 2003), dengan atribusi terhadap diskriminasi (Eccleston \& Major, 2006; Major dkk., 2003), dan kegagalan regulasi diri (Lambird \& Mann, 2007). Terdapat pula penelitian tentang prasangka yang disoroti dari sudut pandang teori management terror (Das, Bushman, Bezemer, Kerkhof \& Vermeulen, 2009). Terkait dengan latar belakang etnis, penelitian terdahulu mengenai harga diri (self-esteem) dan prasangka memberikan temuan yang datanya didapat dari partisipan mahasiswa berbagai etnis. Contohnya penelitian Fein dan Spencer (1997) dilakukan terhadap mahasiswa Amerika, penelitian Sinclair dan Kunda (2000) dilakukan terhadap mahasiswa Kanada, penelitian Collange dkk. (2006) dilakukan terhadap mahasiswa Perancis, penelitian Shapiro, Mistler dan Neuberg (2010), dilakukan terhadap mahasiswi berkulit putih dan hitam di Amerika. Penelitian ini memperluas temuan empiris mengenai harga diri (selfesteem) dan prasangka pada populasi lain, yaitu mahasiswi beretnis Sunda di wilayah Bandung, Indonesia. Temuan yang sejalan dari penelitian-penelitian tersebut, membuat hipotesis mengenai perilaku menghindar dari target beretnis minoritas memperoleh konfirmasi.

\section{Kesimpulan}

Hasil penelitian memperlihatkan bahwa ancaman terhadap harga-diri (selfesteem) diikuti dengan meningkatnya prasangka dan stereotyping, yang dimunculkan dalam bentuk perilaku, yakni perilaku menghindar dari target. Dengan demikian secara umum dapat disimpulkan bahwa hasil penelitian ini memberi konfirmasi pada temuan yang diperoleh dari penelitian-penelitian sebelumnya.

Mempertimbangkan berbagai keterbatasan yang terkandung dalam penelitian ini, beberapa rekomendasi dapat diberikan, yaitu: (1) Mengembangkan penelitian serupa dengan memperhatikan aspek individual dalam motivasi dan emosi, serta kemungkinan menggunakan alat ukur 
yang lebih otomatis, dan (2) Pada tataran praktikal rekomendasi terutama ditujukan untuk menghindari tercetusnya prasangka, seperti: (a) Pengembangan alat asesmen melalui berbagai teknik, misalnya teknik observasi dan wawancara dalam rangka mengenali kondisi-kondisi yang diperkirakan dapat menurunkan hargadiri (self-esteem) seseorang. (b) Pengembangan intervensi untuk mengembangkan harga-diri (self-esteem) positif dan mempertahankan harga-diri (self-esteem) positif.

\section{Kepustakaan}

Allport, G. (1954). The nature of prejudice. Cambridge, Ma: Addison-Wesley

Bargh, J. A., Chen, M., \& Burrows, L. (1996). Automaticity of sosial behavior: Direct effects of trait construct and stereotype activation on action. Journal of Personality and Sosial Psychology, 71, 230-244.

Blair, I. V. (2002). The malleability of automatic stereotypes and prejudice. Personality and Sosial Psychology Review, 6, 242-261.

Collange, J., Benbouzyane, L., \& Sanitioso, R. (2006). Self-image maintenance and discriminatory behavior. Revue Internationale de Psychologie Sosiale, 19, 153171.

Das, E., Bushman, B. J., Bezemer, M. D., Kerkhof, P., \& Vermeulen, I. E. (2009). How terrorism news reports increase prejudice against outgroups: A terror management account. Journal of Experimental Sosial Psychology, 45, 453-459.

Devine, P. G. (1989). Stereotypes and prejudice: Their automatic and controlled components. Journal of Personality and Sosial Psychology, 56, 5-18.

Devine, P. G., Plant, E. A., Amodio, D. M., Harmon-Jones, E., \&Vance, S. L.
(2002). The regulation of explicit and implicit race bias: The role of motivations to respond without prejudice. Journal of Personality and Sosial Psychology, 82, 835-848.

Dovidio, J. F., Gaertner, S. L., Anastasio, P. A., \& Sanitioso, R. (1992). Cognitive and motivational bases of bias: Implications of aversive racism for attitudes toward Hispanics. In S. B. Knouse, P. Rosenfeld, and A. L. Culbertson (Eds.), Hispanics in the workplace. London: Sage Publications.

Eccleston, C. P. \& Major, B. N. (2006). Attributions to Discrimination and Self-Esteem: The Role of Group Identification and Appraisals. Group Processes EIntergroup Relations, 9(2), 147-162.

Fein, S., \& Spencer, S. J. (1997). Prejudice as self-image maintenance: Affirming the self through derogating others. Journal of Personal and Sosial Psychology, 73, 3144.

Flynn, H. K. (2003). Self Esteem Theory and Measurement: A critical review. Diunduh dari: www.thirdspace.ca/ articles/kohlflyn.htm. tanggal 10 Juni 2010.

Hebl, M. R., Foster, J. B., Mannix, L. M., \& Dovidio, J. F. (2002). Formal and interpersonal discrimination: A field study of bias toward homosexual applicants. Personality and Sosial Psychology Bulletin, 28, 815-825.

Lambird, K. H., \& Mann, T. (2007). When Do Ego Threats Lead to Self-Regulation Failure? Negative Consequences of Defensive High Self-Esteem. Personality and Sosial Psychology Bulletin, 32, 1177-1187. online version $\mathrm{http}: / / \mathrm{psp}$. sagepub.com/cgi/content/abstract/32/9 /1177 
Lepore, L., \& Brown, R. (2002). The role of awareness: Divergent automatic stereotype activation and implicit judgment correction. Sosial cognition, 20, 321-351.

Liberman, N., \& Förster, J. (2000). Expression after suppression: A motivational explanation of postsuppressional rebound. Journal of Personality and Sosial Psychology, 79, 190-203.

Macrae, C. N., Bodenhausen, G. V., Milne, A. B. \& Jetten, J. (1994). Out of mind but back in sight: Stereotyped on rebound. Journal of Personality and Sosial Psychology, 67, 808-817.

Major, B., McCoy, S. K., \& Kaiser, C. R. (2003). Prejudice and self-esteem: A transactional model. European Review of Sosial Psychology, 14, 77-104

Myers, D. (2005). Sosial Psychology. New York: McGraw-Hill.

Phelps, E. A., O'Connor, K. J., Cunningham, W. A., Funayama, E. S., Gatenby, J. C., Gore, J. C. \& Banaji, M. R. (2000). Performance on indirect measures of race evaluation predicts amygdala activation. Journal of Cognitive Neuroscience, 12, 729-738.

Plant, E. A., \& Devine, P. G. (1998). Internal and external motivation to respond without prejudice. Journal of Personality and Sosial Psychology, 75, 811-832.
Rosenberg, M. (1965). Society and the adolescent self-image. Princeton, NJ: Princeton University Press.

Setiady, D. A. (2010). Pengaruh pemberian feedback negative terhadap perilaku menghindar: Penelitian mengenai prasangka terhadap etnis Tionghoa. Fakultas Psikologi Universitas Padjadjaran. Jatinangor.

Shapiro, J. R., Mistler, S. A., \& Neuberg, S. L. (2010). Threatened selves and differential prejudice expression by White and Black perceivers. Journal of Experimental Sosial Psychology, 46, 469473.

Sinclair, L., \& Kunda, Z. (2000). Motivated stereotyping of women: She's fine if she praised me but incompetent if she criticized me. Personality and Sosial Psychology Bulletin, 26, 1329-1342.

Sindhunata, G. (2006). Teori Rene Girard: Kambing Hitam. Jakarta: Gramedia.

Spencer, S. J., Fein, S., Wolfe, C. T., Fong, C., \& Dunn, M. A. (1998). Automatic activation of stereotypes: The role of self-image threat. Personality and Sosial Psychology Bulletin, 24, 1139-1152.

Turner, S., \& Allen, P. (2007). Chinese Indonesians in a rapidly changing nation: Pressure of ethnicity and identity. Diunduh dari: http:// ebscohost.com. tanggal 10 Juni 2010. 